Nigel G. Caseby MB, CH B, FFARCS, $\operatorname{rRCP}(C)$

\title{
Postpartum Stroke Successfully Treated with High-Dose Pentobarbitone Therapy: A CASE REPORT
}

A cast is presented of a primigravida with severe preeclampsia who, 24 hours after delivery, became hemiparetic and deeply comatose due to acute ischaemia of the left cerebral hemisphere. She was treated with high dose pentobarbitone therapy when conventional treatment to control raised ICP had failed, A loading dose of perriobarbitone $400 \mathrm{mg}$ ( $5 \mathrm{mg} / \mathrm{kg}$ ) was followed by a continuous infusion of $1.0 \mathrm{to} 2.5 \mathrm{mg} / \mathrm{kg} / \mathrm{hour}$. Withdrawal of the barbiturate after four days of therapy resulted in a rise in ICP above $20 \mathrm{mmHg}$ which necessitated resumption of the drug. After an additional eight days of pentobarbitone therapy with normal ICP values the infusion was discontinued without any change in ICP. The patient made an excellent recovery with no neurologic deficit.

The specific pathophysiologic features of pre-eclampsia which were encountered in the patient are detailed. The poiential problems which may arise in the pre-eclamptic patient who requires intensive care in the puerperium are emphasised.

\section{Key Words}

HYPNOTICS: pentobarbitone; PREGNANCY: complications, coma.

From the Department of Anaesthesia, Health Sciences Centre, Memorial University of Newfoundland, St. John's, Newfoundland.

Address correspondence to: Dr. Nigel G. Caseby, Department of Anaesthesia, University of Toronto, Toronto General Hospital, 101 College Street, Toronto, Ontario MSG 1 L7.
Pre-eclampsia and eclampsia are responsible for up to 25 per cent of all maternal deaths from obstetrical causes. ${ }^{1-3}$ The majority of these deaths result from cerebrovascular accidents although renal failure, heart failure, disseminated intravascular coagulation, hepatic coma and respiratory failure also contribute. ${ }^{1-4}$ Cerebral haemorrhage is the commonest cause of death and is found in over 50 per cent of patients who die following eclampsia. ${ }^{3,4}$ Other neurologic causes of death include cerebral infarction consequent to arterial embolism, thrombosis or spasm, cerebral venous thrombosis, and cerebral oedema. ${ }^{1-6}$

During the past decade there have been dramatic advances in the monitoring and treatment of neurologic disorders. The effectiveness of intracranial pressure (ICP) monitoring in identifying early changes in cerebral function has led to a more rational application of standard therapeutic measures. ${ }^{7,8}$ Conventional treatment for disorders with raised ICP includes osmotherapy, diuretics, glucocorticoids, controlled hyperventilation, vasodilator therapy, and hypothermia. Recently high-dose barbiturate therapy has been introduced following its beneficial effect in animal experimental models of ischaemic stroke. ${ }^{9-12}$ However, barbiturates have not been shown to improve outcome in humans with stroke, although an increased survival has been documented in patients with heac injury and acute metabolic and infective cerebral damage. ${ }^{13-15}$

There are no reports in the literature regarding the application of modern neurologic intensive care techniques to the treatment of cerebral damage consequent to pre-eclampsia and eclampsia. The following case report details the management of a 
patient with pre-eclampsia who had a severe ischaemic stroke 24 hours after delivery.

\section{Case History}

A 26 year-old primigravida was admitted at 33 weeks gestation with severe pre-eclampsia. She had $3+$ proteinuria, generalised oedema, hyperactive reflexes, and a blood pressure (BP) of $25,3 / 14.6 \mathrm{kPa}$ $(190 / 110 \mathrm{mmHg})$. She complained of persistent frontal headache, epigastric pain, and blurred vision. Her weight gain during pregnancy was $14.5 \mathrm{~kg}$. Intravenous magnesium sulphate and hy dralazine were started. The initial response to antihypertensive therapy was good but, despite continuing treatment, her $\mathrm{BP}$ rose again to 26.61 $14.6 \mathrm{kPa}(200 / 110 \mathrm{mmHg})$. On the third hospital day a decision was made to perform a Caesarean section under general anaesthesia. A healthy female infant was delivered

Following the operation the patient was conversing appropriately and obeying commands. Therapy was continued with hydralazine and magnesium sulphate. Phenobarbitone was added. However, despite therapy the BP remained at $24 / 15.3 \mathrm{kPa}$ $(180 / 115 \mathrm{mmHg})$. On the fourth hospital day, exactly 24 hours postpartum, the patient suddenly became deeply comatose with responses only to painful stimuli. On examination she had a fixed and dilated left pupil, a right hemiparesis, and bilateral papilloedema. Her BP was $29.3 / 17.3 \mathrm{kPa}(220 /$ $130 \mathrm{mmHg}$ ). No seizure was witnessed. The diagnosis of left hemisphere stroke was made.

Dexamethasone $40 \mathrm{mg}$ was given intravenously and mannitol $100 \mathrm{~g}$ was infused over 30 minutes. The left pupil became reactive and less dilated. The patient began to move her left side spontaneously as well as to command, but the right side remained paretic. Following this therapeutic response a left carotid angiogram was performed under general anaesthesia with mechanical hyperventilation. The angiogram showed swelling of the whole left hemisphere with some transtentorial hemiation; the parieto-occipital area was particularly swollen with poor filling and obliteration of many of the arteries in that region. The patient was then taken directly to the operating room where a catheter was inserted in the right lateral ventricle through a frontal Burr hole. Cerebrospinal fluid was clear with a potassium of $3.3 \mathrm{mEq} / \mathrm{l}$. The initial ICP measurement was $2.66 \mathrm{kPa}(20 \mathrm{mmHg})$. During these diagnostic and operative procedures an additional $100 \mathrm{~g}$ mannitol was infused.

On admission to the intensive care unit (ICU) continuous intra-arterial BP and ICP monitoring were established. A central venous pressure (CVP) line was inserted. Mechanical ventilation was adjusted to achieve an arterial carbon dioxide tension $\left(\mathrm{PaCO}_{2}\right)$ of about $3.33 \mathrm{kPa}(25 \mathrm{mmHg})$ and an arterial oxygen tension $\left(\mathrm{PaO}_{2}\right)$ of $13.3 \mathrm{kPa}$ (100 mmHg). Both ICP and systolic BP were found to be labile, ranging from 2.0 to $4.0 \mathrm{kPa}$ (15 to $30 \mathrm{mmHg}$ ) and 16.0 to $24.0 \mathrm{kPa}(120$ to $180 \mathrm{mmHg}$ ) respectively. Each time the ICP rose above $2.66 \mathrm{kPa}(20 \mathrm{mmHg})$ for more than three minutes mannitol $20 \mathrm{~g}$ was given. After three hours of mechanical hyperventilation and intemittent mannitol therapy it became increasingly difficult to keep the ICP below $2.66 \mathrm{kPa}(20 \mathrm{mmHg})$. Because of this developing resistance to mannitol a decision was made to institute high-dose barbiturate therapy. Therefore, six hours after the occurrence of the stroke, a bolus of pentobarbitone $400 \mathrm{mg}(5 \mathrm{mg} / \mathrm{kg})$ was given intravenously followed by a maintenance infusion of $200 \mathrm{mg}$ per hour. Within a few minutes of initiating barbiturate therapy, the ICP had fallen to normal levels and from this point onwards the ICP remained well controlled at less than $2.66 \mathrm{kPa}$ (20 mmHg). Mean BP also fell to acceptable levels of 10.6 to $12.0 \mathrm{kPa}$ ( 80 to $90 \mathrm{mmHg}$ ) thus ensuring an adequate cerebral perfusion pressure (CPP) of more than $8.0 \mathrm{kPa}(60 \mathrm{mmHg})$.

Barbiturate therapy was continued for the next four days (Figure 1). Pentobarbitone was titrated to achieve an ICP of less than $2.66 \mathrm{kPa}(20 \mathrm{mmHg})$, a motionless patient, a mean BP of 9.3 to $13.3 \mathrm{kPa}$ (70 to $100 \mathrm{mmHg}$ ), a CPP of more than $6.7 \mathrm{kPa}$ $(50 \mathrm{mmHg})$, and a serum pentobarbitone level of $25-40 \mathrm{mg} / \mathrm{litre}$. The patient required between 2.5 to $1.0 \mathrm{mg} / \mathrm{kg} /$ hour pentobarbitone by syringe pump. Thirty hours after withdrawal of the barbiturate therapy the ICP rose again to more than $2.66 \mathrm{kPa}$ (20 $\mathrm{mmHg}$ ) and mannitol therapy was reinstituted. There was a concomitant rise in BP. The patient remained in a coma. Because of an increasing requirement for mannitol to control ICP, barbiturate therapy was recommenced. A rapid return to nomal values of ICP occurred. High-dose pentobarbitone therapy was maintained for a further eight days. Before discontinuing the barbiturate infusion on this occasion a normal intracranial volume/pres- 


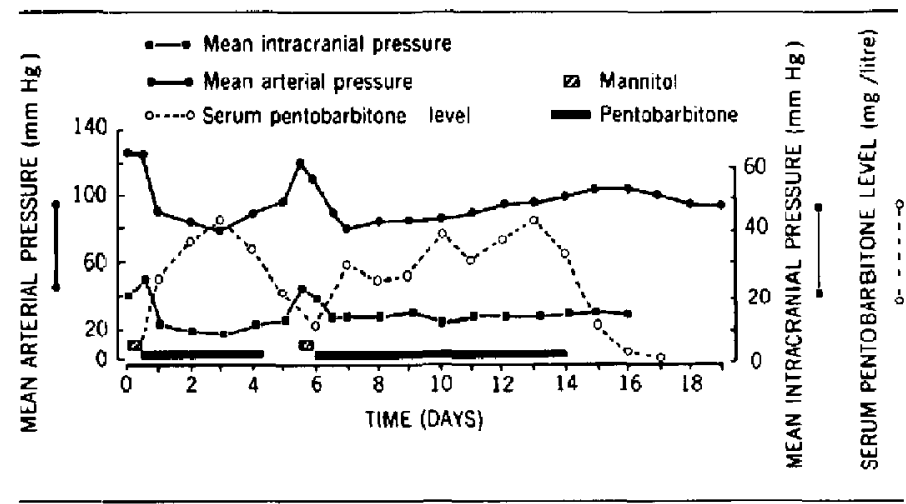

FIGURE 1 Clinical course of the patient and main dnig therapy after the occurrence of an ischaemic stroke. Mean ICP and BP were controlled by a continuous infusion of pentobarbitone. Mannitol was given intermittently where indicated. Refer to the text for details.

sure response was elicited, i.e. a rise in ICP of less than $0.4 \mathrm{kPa}(3 \mathrm{mmHg})$ with $1 \mathrm{ml}$ saline injected through the ventricular catheter. After withdrawal of the barbiturate a rise in $\mathrm{BP}$ occurred, but the ICP remained normal at $2.0 \mathrm{kPa}(15 \mathrm{mmHg})$. Methyldopa was commenced for BP control. The ventricular catheter was removed after 16 days.

During the two periods of therapeutic barbiturate coma many additional measures were employed to aid in the reduction of ICP and protection of the brain:

1 Steroid therapy: Dexamethasone was given for 19 days with an initial dose of $80 \mathrm{mg} /$ day and a reducing dose schedule.

2 Controlled hyperventilation: $\mathrm{PaCO}_{2}$ was maintained at $3.33 \mathrm{kPa}$ ( $25 \mathrm{mmHg}$ ) for the first two days then gradually allowed to retum to normal Mechanical ventilation was carried out for 17 days. 3 Moderate hypothermia: The patient's temperature was cooled to $32-33^{\circ} \mathrm{C}$ during both periods of barbiturate therapy. Body temperature was returned to norinal before barbiturate withdrawal.

4 Fluid restriction and loop dituretics: A negative fluid balance was sought. Furosemide was used on a few occasions.

5 Head elevation: The head was raised 15-20 degress to aid venous drainage from the brain.

Two days after cessation of pentobarbitone therapy the patient was moving all of her limbs and obeying commands. Her pupils remained equal and reactive. Spontaneous breathing was quickly resumed and mechanical ventilation was withdrawn.
Thereafter her neurologic recovery was rapid. Within one week she was using all her limbs in a purposeful manner. She was fully orientated and had normal mental functions. Her remarkable neurologic recovery continued. The only problem during her recovery was the occurrence of several grand mal seizures which were controlled with therapeutic doses of phenytoin and phenobarbitone. An electroencephalogram during the period of seizures showed diffuse epileptogenic abnormalities in both cerebral hemispheres, the right more than the left. A repeat left carotid angiogram, 35 days after the stroke, showed resolution of the previous swelling and a return of normal arterial perfusion. Seven weeks after admission to hospital the patient was discharged home on phenytoin, phenobarbitone and methyldopa medications. She had no neurologic deficit and was able to care for herself and her baby. All drug therapy was successfully discontinued within 13 months of discharge from the hospital.

\section{Discussion}

The occurrence of an ischaemic stroke during pregnancy or the puerperium is associated with a 30 per cent mortality and considerable physical disability in the survivors. ${ }^{16-18}$ This death rate is three times greater than the incidence found in nonpregnant female stroke victims of childbearing age. ${ }^{18}$ In the present case angiographic findings indicated that the severe ischaemic stroke was due to focal occlusive arterial disease which had prob- 
ably resulted from a combination of thrombosis and vasospasm.

Barbiturates have been advocated in the treatment of a variety of cerebral disorders where there is failure of standard measures to control ICP..$^{8.13-15}$ On the basis of the satisfactory outcome in our patient, full scale monitoring and supportive treatment including high-dose barbiturate therapy can be recommended for ischaemic brain protection in pre-eclamptic patients who demonstrate acutc neurologic decompensation. However, before barbiturate coma is induced there are four pre-conditions which must be satisfied. Firstly, where the patient is antepartum the expeditious delivery of the foetus and, most importantly, the placenta by Caesarean section takes priority. Secondly, a pathologic diagnosis of the brain disorder must be established by computerised tomography and/or cerebral angiogtaphy. Thirdly, any surgical lesion, e.g. a large intracerebral haematoma, must be treated adequately. Fourthly, there should be a demonstrated failure of conventional treatment to control intracranial hypertension.

The two most important beneficial effects of high-dose barbituratc administration are a reduction in ICP and a prolective effect on the ischaemic brain. Many human studies have shown that barbiturates can rapidly lower ICP even where control of ICP cannot be achieved by conventional treatment, and that the continuous infusion of barbiturates can control ICP for prolonged periods. ${ }^{13-15,19,20}$ Barbiturates may reduce ICP by increasing cerebrovascular resistance and lowering ccrebral blood volume. Therefore, CPP may increase providing that mean BP remains normal, and cerebral blood flow may actually improve. The inability of barbiturates to reduce ICP must be considered a grave prognostic sign. ${ }^{13}$

The mechanism of the protective effect of barbiturates on the ischaemic brain is uncertain. Multiple mechanisms have been proposed: reduction of cerebral metabolism; ${ }^{12}$ increase in cerebrovascular resistance in normal areas of brain with diversion of blood to ischaemic areas; ${ }^{9,21}$ suppression of subclinical convulsions; free radical neutralisation or scavenging,; ${ }^{22}$ alteration of arachidonic acid liberation and amino acid metabolism; ${ }^{23,24}$ and possible stabilization of haeme-coordinated iron complexes. ${ }^{25}$
Animal stroke models have shown that irreversible brain damage may not occur for as long as three hours following occlusion of a single major vessel. ${ }^{26}$ Treatment initiated with barbiturates during this potentially reversible period has been proven to be beneficial in many animal studies. ${ }^{9.11 .12}$ However, barbiturate protection of the brain in humans with stroke has not yet been documented. ${ }^{13,27}$ In fact, Rockoff et al. reported a mortality of 100 per cent in four normothermic patients with stroke whose ICP was well controlled with pentobarbitone; on withdrawal of the barbiturate, after five days therapy, a fatal rise in the ICP occurred in each case. ${ }^{13}$

It is tempting to conclude that the satisfactory outcome in the present case may be due to the prolonged period of 12 days of high-dose barbiturate therapy. On the other hand, factors such as the absence of a major cerebral artery occlusion or induced hypothermia may have contributed to the result. The use of hypothermia in brain injury is controversial even though a decrease in cerebral metabolism consistently occurs with a fall in body temperature. No evidence of brain protection was observed in monkey stroke models who were treated with hypothermia at $29^{\circ} \mathrm{C} .{ }^{28}$ However, recent animal research suggests that modest falls in body temperature may provide cerebral protection, and that the combined use of mild hypothermia and pentobarbitone is more beneficial than hypothermia alone. ${ }^{29-31}$.

Barbiturate therapy offers other advantages: a lower requirement for osmotic agents has been reported; 8,13 barbiturates facilitate BP control in hypertensive patients and may obviate the need for anti-hypertensive drugs as demonstrated in the present case; the assocjated immobilisation of the body which accompanies high-dose barbiturate therapy aids with mechanical ventilation and nursing care. However, barbiturate therapy is not without its risks although these are considered small in a well organised ICU. ${ }^{13}$ The potential for myocardial depression from barbiturates exists, therefore, BP must be measured directly and CPP maintained. Barbiturates cause a dose-dependent inhibition of phagocytic activity and may, therefore, predispose to infection. ${ }^{32}$

Although the major effects of pre-eclampsia are most obvious in the maternal cardiovascular sys- 
tem, the pathophysiology of the disease involves every major organ system. ${ }^{5,33}$ In addition to her cerebral involvement, our patient manifested renal, hepatic and coagulation-fibrinolytic system disorders. Haematologic tests 24 hours postpartum revealed a picture of developing disseminated intravascular coagulation: a low platclet count $(26$ $\times 10^{9}$ cells $/$ ), an increase in fibrin degradation products (FDP) $(>80$ but $<160 \mathrm{mg} / \mathrm{l})$ and schistocytes in the blood smear. The patient was given 10 units of platelet concentrate intravenously causing her platelet count to rise to $48 \times 10^{9}$ cells $/$. During the course of her stay in the ICU there was no further haematologic problem. Daily platelet counts showed a spontaneous rise with time to normal values and the FDP levels fell to normal.

In the immediate postpartum period the patient had evidence of hepatocellular damage (bilirubin $39.3 \mu \mathrm{mol} / 1$, alkaline phosphatase $264 \mathrm{U} / \mathrm{l}$, lactic dehydrogenase $>3000 \mathrm{U} / \mathrm{l}$, serum glutamic oxaloacetic transaminase $>1500 \mathrm{U} / \mathrm{l}$ ) and mild renal impairment (creatinine $115 \mu \mathrm{mol} / \mathrm{l}$, uric acid $0.43 \mathrm{mmol} / \mathrm{l}$ ). This organ dysfunction quickly resolved and within a few days all biochemical tests of hepatic and renal function were normal.

The parturient patient differs from normal women in many respects, both anatomically and physiologically. One important difference is the great increase in total body water which occurs during pregnancy. $5,33,34$ Normal pregnancy is accompanied by the retention of about $900 \mathrm{mEq}$ of sodiurn and a proportionate 6 litres increase in body water. ${ }^{34}$ In pre-eclampsia, by some mechanism which is unclear, the increase in body water is even greater. This excess body water is normally excreted in the puerperium and, therefore, a negative fluid balance in the early postpartum period is to be expected. ${ }^{33}$ The present case demonstrated this point well. Over a 24-day period there was a measured negative fluid balance of six litres. If a conservative estimate of a daily insensible fluid loss of 0.5 litres is made, then over that same time period the palient had a fluid deficit of 18 litres.

Other potential features which distinguish the pre-eclamptic patient from the normal parturient are hypovolaemia and hypoalbuminaemia. It is well documented that patients with pre-eclampsia have a contracted blood volume. In those with severe pre-eclampsia the normal hypervolaemia of preg- nancy may be reduced by $60-75$ per cent. ${ }^{35,36}$ The use of a balloon flotation catheter or a CVP line is mandatory, therefore, to monitor the need for blood volume expansion.

The urine in pre-eclampsia contains albumin, transferrin and $\mathrm{IgG}$. Heavy proteinuria may result in a decrease in the serum concentrations of these proteins. ${ }^{37}$ This proteinuria continues in the puerperium but usually resolves within a few weeks of delivery. However, obstetric patients who require intensive care may need correction of their hypoalbuminaemia for optimal management. Our patient had a daily protein loss of $9 \mathrm{~g}$ in the early puerperium but this had decreased to 3 g/day by the fourth week. During her 24 days in the ICU she required an average of $25 \mathrm{~g}$ human serum albumin ( 25 per cent) per day to maintain her serum albumin level between 30 and $40 \mathrm{~g} / \mathrm{l}$. An adequate nutritional intake is important in critically ill pre-eclamptic patients.

Cerebral injury produced by either haemorrhagic or ischaemic stroke is the most serious consequence of the many maternal complications which may occur in severe pre-eclampsia. The application of modem neurologic intensive care principles and practice offers new hope in this life threatening and disabling complication of pregnancy.

\section{Acknowledgements}

My thanks are extended to my medical and nursing colleagues in the ICU, Health Sciences Centre, St. John's, for their assistance in treating the patient; to Dr. F.B. Maroun for permission to report the case; and to Dr. A.A. Scott for reading the manuscript. Figure 1 was produced by the Department of Medical Photography and Art, Toronto General Hospital.

\section{References}

1 Gibbs CE, Locke WE, Maternal deaths in Texas 1969 to 1973. A report of 501 consecutive matemal deaths from the Texas Medical Association's Committee on Maternal Health. Am J Obstet Gynecol 1976; 126: 687-92.

2 Hibbard LT. Maternal mortality due to acute toxemia. Obstet Gynecol' 1973; 42: 263-70.

3 Department of Health and Social Security. Report on confidential enquiries into maternal deaths in Eng- 
land and Wales. 1973-75. London: H.M. Stationery Office 1979; pp. $21-9$.

4 Ferris TF. Toxemia and hypertension. In Medical Complications during Pregnancy. (ed.) Burrow, GN \& Ferris, TF. Philadelphia: Saunders, 1975; pp. 53-104.

5 Donaldsan JO. Neurology of Pregnancy. Philadelphia: Saunders, 1978; pp. 211-50.

6 Jewett $J F$. Fatal intracranial edema from eclampsia. N Eng J Med 1973; 289: 976-7.

7 Schuz $H$, Taylor $F A$. Intracranial pressure and cere bral blood flow monitoring in head injuries. Can Med Ass J 1977; 116; 609-13.

8 Marsh ML, Marshall LF, Shapiro HM. Neurosurgical intensive care. Anesthesiology 1977; 47: 149-63.

9 Smith AL, Hoff JT, Nieisen SL, Larson CP. Barbiturate protection in acute focal cerebral ischemia. Stroke $1974 ; 5: 1-7$

10 Hoff JT, Smith AL, Hankinson HL, Nielsen SL. Barbiturate protection from cerebral infarction in primates. Stroke 1975; 6: 28-33.

11 Maseley JI, Laurent JP, Molinari GF. Barbiturate attenuation of the clinical course and pathologic lesions in a primate stroke model. Neurology 1975; 25: 870-4.

12 Michenfelder JD, Milde JH, Sund TM Jr. Cerebral protection by barbiturate anesthesia; use after middle cerebral artery occlusion in Java monkeys. Arch Neurol 1976; 33: 345-50.

13 Rockoff MA, Marshall LF, Shapiro HM. Highdose barbiturate therapy in humans: a clinical review of 60 patients. Ann Neurol 1979; 6: 194-9.

14 Marshall LF, Shapiro HM. Rauscher A, Kaufman NM. Pentobarbital therapy for intracranial hypertension in metabolic coma. Reye's syndrome. Crit Care Med 1978; 6: 1-5.

15 Marshall LF, Smith RW, Shapiro HM. The outcome with aggressive treatment in severe head injuries. Part II: Acute and chronic barbiturate administration in the management of head injury. J Neurosurg 1979; 50: 26-30.

16 Amias AG. Cerebral vascular disease in pregnancy 2-Oeclusion. J Obstet Gynaecol Br Commonw 1970; 77: 312-25.

17 Cross JN, Castro PO, Jennen WB. Cerebral strokes associated with pregnancy and the puerperium. Br Med J 1968; 3:214-8

18 Jennett $W B$, Cross $J N$. Influence of pregnancy and oral contraception on the incidence of strokes in women of childbearing age. Lancet 1967; 1 10]9-23.

19 Shapiro HM, Galindo A, Wyte SR, Harris AB Rapid intra-operative reduction of intracranial pressure with thiopentone. Br J Anaesth 1973; 45: 1057-62.

20 Shapiro HM, Wyte SR, Loeser J. Barbiturateaugmented hypothermia for reduction of persistent intracranial hypertension. J Neurosurg 1974; 40: 90-100.

21 Hanson J, Anderson R, Sundt TM Jr. Influence of cerebral vasoconstricting and vasodilating agents on blood flow in regions of cerebral ischemia. Stroke $1975 ; 6 ; 642-8$.

22 Flamm ES, Demopoulos HB, Seligman ML, Poser $R G$, Rarsohoff $J$. Free radicals in cerebral ischemia. Stroke 1978; 9: 445-7.

23 Magalini SI, Bondoli A, Corrado M. Protective effect of phenobarbital on amino-acid cerebral metabolism on expcrimental acute hypoxia. Crit Care Med 1981; 9: 249.

24 Shiu GK, Nemoto EM, Bleyaert AL, Nemmer J. Comparison of pentobarbital, etomidate and halothane in attenuation of brain free fatty acid liberation dusing complete global ischemia. Crit Care Med 1981;9: 184.

25 Godin DV, Mitchell MJ, Saunders BA. Studics on the interaction of barbjturates with reactive $D x y$ gen radicals: implications regarding barbiturate protection against cerebral ischaemia. Can Anaesth Soc J 1982; 29: 203-11

26 Sundt TM Jr, Grant WC, Garcia JH. Restoration of middle cerebral artery flow in experimental infarction. J Neurosurg 1969; 31: 311-22.

27 Christensen MS, Paulson OB, Oleson J, Alexander SC, Skinhøj E, Dam WH, Lassen NA. Cerebral apoplexy (stroke) treated with or without prolonged artificial hyperventilation: I cerebral circulation, clinical course, and cause of death. Stroke 1973; 4: 568-631.

28 Michenfelder $J D$, Milde $J H$. Failure of prolonged hypocapnia, hypothermia, or hypertension to favorably alter acute stroke in primates. Stroke $1977 ; 8$ : 87-91.

29 Lafferty J, Keykhah MM, Shapiro HM, Van Horn $K$, Behar $M G$. Cerebral hypometabolism obtained with deep pentobarbital anesthesia and hypothermia (30C). Anesthesiology 1978; 49: 159-64. 
30 Berntman L, Welsh FA, Harp JR. Cerebral protective effect of low-grade hypothermia. Anesthesiology $1981 ; 55: 495-8$.

31 Artru AA, Michenfelder $J D$. Influence of hypothermia or hyperthermia alone or in combination with pentobarbital or phenytoin on survival time in hypoxic mice. Anesth Analg 1981; 60: 867-70.

32 Moudgil GC. Effects of premedicants, intravenous anaesthetic agents and local anaesthetics on phagocytosis in vitro. Can Anaesth Soc J 1981; 28: 597-602.

33 Pritchard JA, MacDonald PC (ed). Hypertensive disorders in pregnancy. In, Williams Obstetrics, 16 th ed. New York: Appleton-Century-Crofts 1980; pp. 665-700.

34 Chesley LC. Disorders of the kidney, fluids and electrolytes, In, Pathophysiology of Gestation. Volume 1, Matemal Disorders: (ed). Assali NS, Brinkman CR. New York: Academic Press, 1972; pp. 356-478.

35 Blekta M, Hlavaty V, Trnkova M, Bendl J, Bendova $L$. Chytil $M$. Volume of whole blood and absolute amount of serum proteins in the early stage of late toxemia of pregnancy. Am J Obstet Gynecol 1970; 106: 10-13.

36 Soffronoff $E C$, Kaufmarn BM, Connaughton $J F$. Intravascular volume determinations and fetal outcome in hypertensive diseases of pregnancy. Am J Obstet Gynecol 1977; 127: 4-9.

37 Studd $J$. The origin and effects of proteinuria in pregnancy. J Obstet Gynaecol Br Commonw 1973; 80: 872-83.
Résumé

On rapporte un cas de primigeste accompagné de sévère prééclampsie qui, après l'accouchement, manifesta un état d' hémiparésie et devint gravement comateux causé par une grave ischémie au côté gauche de l'hémisphère cérébral. Cette patiente a été soignée avec une forte dose de pentobarbitone lorsque le traitement conventionnel de controle pour hausser le ICP échoua. Une dose surchargée de pentobarbitone $400 \mathrm{mg}$ ( $5 \mathrm{mg} / \mathrm{kg}$ ) fut auministrée par infusion continuelle de $1.0 \mathrm{~d} 2.5 \mathrm{mg}$ ! $\mathrm{kg} / \mathrm{heure}$. Après quatre jours de cette thérapie, l'arrêt du barbiturate engendra une hausse du ICP, au-dessus de $20 \mathrm{mmHg}$ qui nécessita la reprise du médicament. Après huit jours de therapie au pentobarbitone lorsque les valeurs normales du ICP furent obtenues, on arrêta le traitement sany remarquer de changement au ICP. La patiente fit d' excellents progrès et récupéra sans troubles neurologiques.

Les mantifestations spécifiques et pathophysiologigues de la préćclampsie observées chez la patiente sont détaillées. Les troubles éventwels qui peuvent se produire chez les patientes sujettes à la prééclampsie et qui ont besoin de soins intensifs dans la période du puerperium sont soulignés. 